\title{
SOURCES OF FIXED INVESTMENT: CHARACTERISTICS OF INVESTMENT PAUSE ${ }^{1}$ O.Berezinskaya, M.Khromov
}

The Russian economy entered a period of investment pause in 2013. In terms of financial resources available for the investment process, it is characterized by substantial increase in enterprise self-financing for investment projects with cutbacks in financing through external borrowing. The foregoing developments were observed amid shrinkage of financial resources available in the economy. Activating the investment process through economic enterprises' own resources is an option that can alleviate the investment decline.

The issue of limited resources is still relevant in discussions on fixed investment that have been held in recent years. In 2014/2015, the investment process became more limited for Russia and the economy was found itself in the investment pause.

Gross disposable income - GDP (volume) adjusted for BOP non-trade current account transactions, representing all the current year earnings of economic agents - forms the basis for generating financial resources in the economy.

Final consumption expenditure derive from gross disposable income, and the remainder of financial resources make up gross savings in the economy. Comparing gross savings with gross accumulation (a broad definition of fixed investment, including fixed asset renewal costs (repairs) as well as changes in inventories) shows the extent to which savings are transformed into investment in the economy. The difference between these indicators represents net credit to the rest of the world.

However, besides gross savings, funds raised from foreign investors can be harnessed as resources for investment, too. Besides gross accumulation, investment in foreign assets is an alternative way of allocating financial resources.

Since the mid-2000s, there has been correlation between the dynamics of fixed investment and the volume of financial resources available in the Russian economy (a total of gross savings and funds raised from abroad). This substantiates the apparent regularity: declining savings and a lack of external loans tend to spur a decline in investment. The financial resources available in the Russian economy were facing a steady decline from $31 \%$ of GDP in 2011 down to 19\% of GDP in 2015. Considering the same period, the

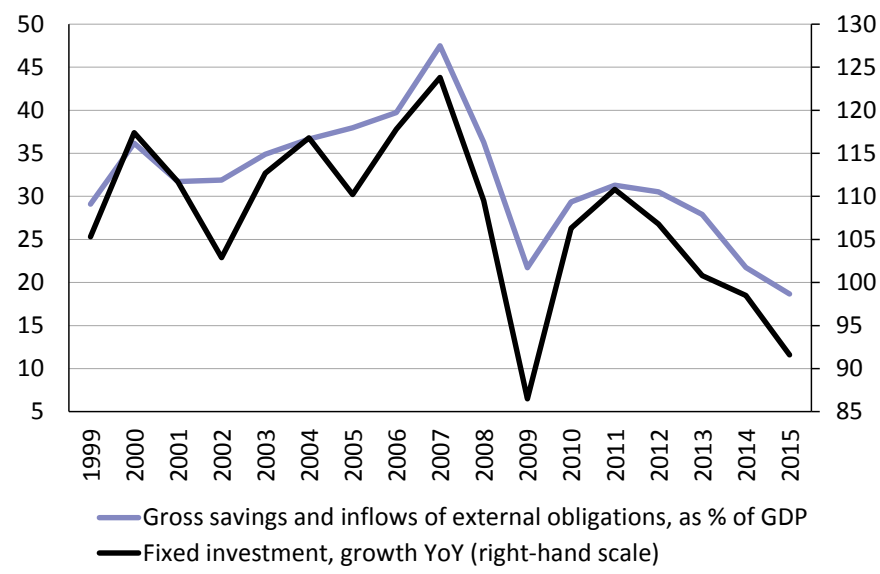

Fig. 1. Investment dynamics and share of financial resources available in the economy of Russia

1 This paper was originally published in Online Monitoring of Russia's Economic Outlook No.12(30). 
dynamics of fixed investment worsened from a hike of $10.8 \%$ in 2011 down to a fall of $8.4 \%$ in 2015.

Economic enterprises' own resources were the major source of finance for fixed investment in the period between 1999 and 2015. Since 2010 they have been playing an increasingly important role in providing resources for the investment process.

Up until 2009, the expansion of fixed investment was governed by growth in financing from raising non-public funds, with public funds becoming less important in supporting the investment process and with slower growth in enterprises' self-financing for investment projects.

The expansion of fixed investment in the period between 2010 and 2015 was driven mainly by growth in financing fixed investment from enterprises' own resources amid unstable dynamics of investment project financing from Russian bank loans, as well as deteriorated dynamics of raising other nonpublic funds and of state support to economic enterprises with regard to fixed investment.

In the period between 2013 and 2015, fixed investment financing was characterized as follows:

- more than $51 \%$ of fixed investments were financed from enterprises' own resources (37\% in 2009), and enterprises' self-financing for investment projects continued to grow at faster than normal rates;

- state support to the investment process decreased, less than $17 \%$ of investments were financed from budget and off-budget funds (22\% in 2009);

- Russian bank investment loans continued to be weak and unstable: Russian bank loans accounted for less than $6 \%$ of investment financing (7.2\% in 2009);

- investment financing from funds allocated by senior organizations (e.g., holding companies) dropped sharply to account for $10.5 \%$

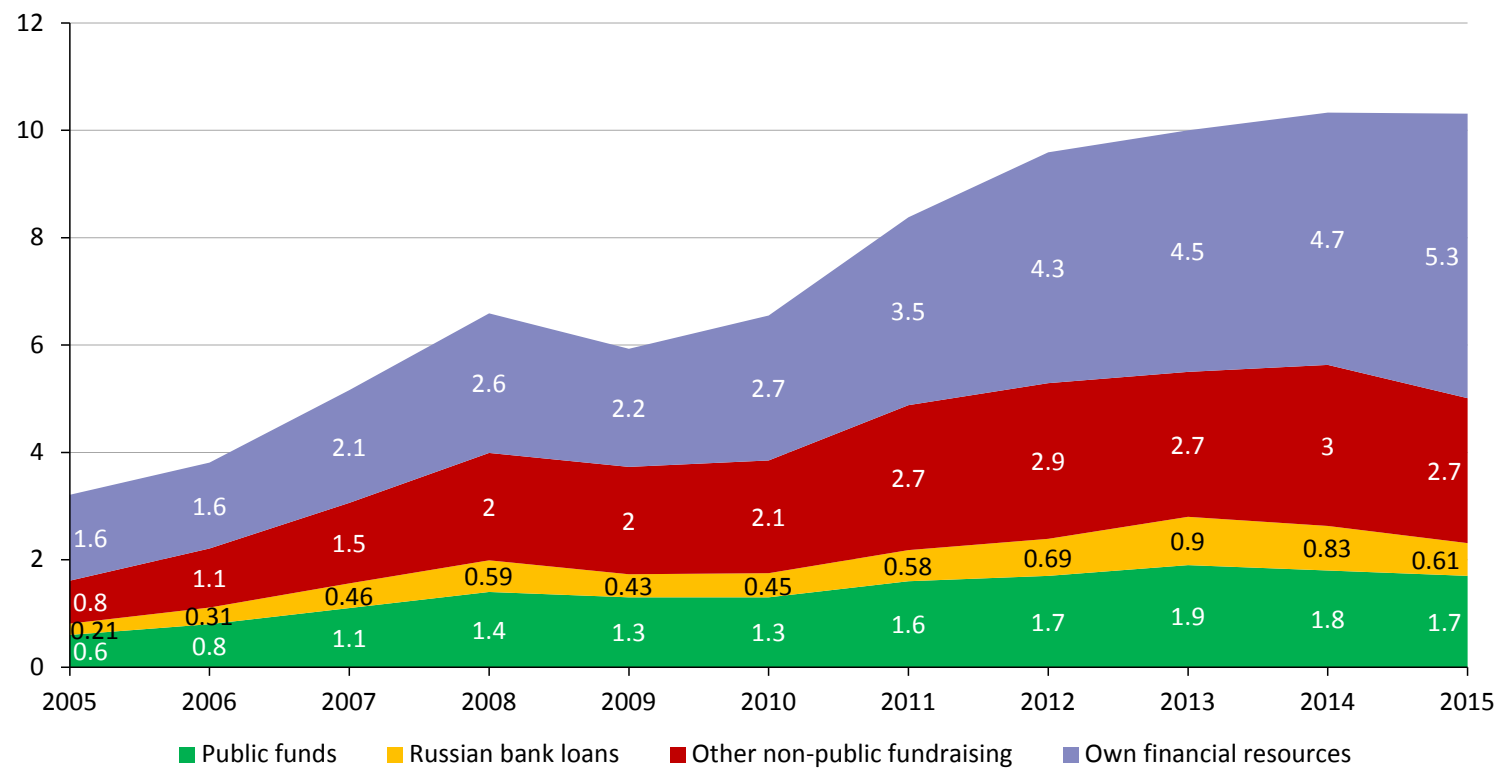

Note: Public funds refer to budget and off-budget funds; Other non-public fundraising refer to all the funds raised, except Russian bank loans and public funds.

Sources: Rosstat (Russia's Federal State Statistics Service), own calculations.

Fig. 2. Structure of sources of finance for fixed investment in the Russian economy in 2005-2015, roubles in trillion 
of the investment source structure in 2015 compared to $17.8 \%$ in the period between 2010 and 2012; this was due to sanctions that restrict Russian companies' access to financial resources in global markets;

- investments from other resources (e.g., borrowings from other organizations, fundraising through stocks, corporate bonds) increased at the start of the investment pause and remained unchanged in 2015, that is, economic enterprises had extremely limited opportunities to compensate for the lack of financing from alternative sources.

Fixed investment finance faced substantially limited resources in the period between 2013 and 2015. The crisis-hit structure of sources of fixed investment finance was driven by a few factors: the state was less able to support the investment process, banks enhanced diligence in long-term lending in the period of economic downturn, enterprises of the real and financial sectors of the Russian economy were restricted from accessing financial resources in global markets. More than a half of all the fixed investments were financed from enterprises' own resources.

In the period of investment pause, with severely limited resources, enterprises' self-financing for investment projects is considered basically the sole real resource that can boost the investment process in the Russian economy. To kick off this resource, (1) economic enterprises' own resources for investment should be generated in increasing volumes, and (2) their motivation to invest own resources in business development should be elevated.

In 2014, the volume of economic enterprises' own resources for investment amounted to $\mathrm{Rb} 11.8$ trillion, that is, a total of amortization and disposable profit (profit left over after paying profit tax). Importantly, in 20122013 enterprises' own resources for investment increased insignificantly by $\mathrm{Rb} 0.5$ trillion a year, in 2014 they increased by Rb 1.7 trillion, and in 2015 they exceeded, according to our estimations, Rb 2 trillion (no 2015 end-ofyear statistics are available yet).

Table 1

GENERATION OF OWN RESOURCES FOR INVESTMENT IN THE RUSSIAN ECONOMY IN 2011-2015

\begin{tabular}{|c|c|c|c|c|c|}
\hline & 2011 & 2012 & 2013 & 2014 & 2015 \\
\hline Profit, roubles in trillions & 8.5 & 8.8 & 8.4 & 9.4 & 11.3 \\
\hline Profit tax paid, roubles in trillions & 2.3 & 2.4 & 2.1 & 2.3 & 2.4 \\
\hline $\begin{array}{l}\text { Disposable profit, roubles in trillions } \\
\text { (line } 1 \text { less line } 2 \text { ) }\end{array}$ & 6.3 & 6.4 & 6.4 & 7.3 & 8.8 \\
\hline Amortization, roubles in trillions & 2.8 & 3.3 & 3.7 & 4.7 & $5.2^{*}$ \\
\hline $\begin{array}{l}\text { Own resources for investment, roubles in } \\
\text { trillions } \\
\text { (total of lines } 3 \text { and } 4 \text { ) }\end{array}$ & 9.1 & 9.7 & 10.1 & 11.8 & $14.0^{*}$ \\
\hline
\end{tabular}

Enterprises' self-financing for investment projects has increased in terms of utility amid severely restricted access to resources, and economic enterprises do have an opportunity to activate the investment process using their own resources.

The propensity to finance investment from own resources (the ratio of fixed investment from own resources to the volume of own investment 


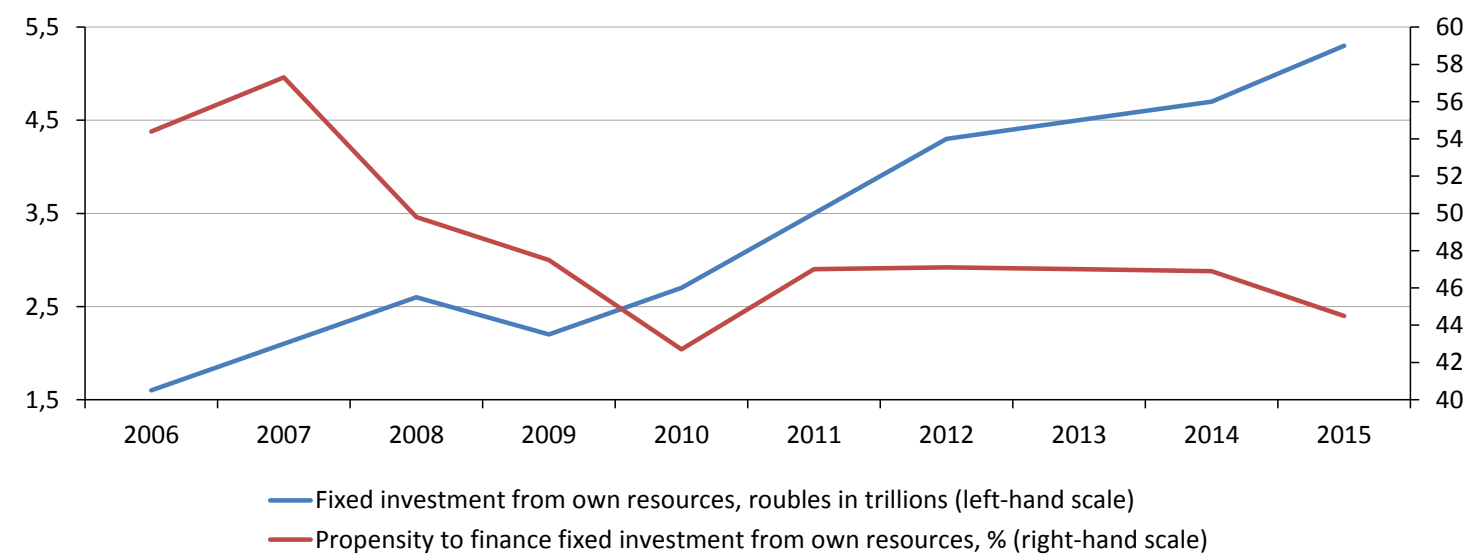

Sources: Rosstat, own calculations.

Fig. 3. Dynamics of fixed investment financing from own resources and economic enterprises' propensity to finance investments from own resources in 2006-2015

resources earned in previous year) for a few years stood at a stable level of about $47 \%$, but in 2015 it dropped markedly down to $44.5 \%$.

With the same level of enterprises' propensity to finance investments from own resources, fixed investment from own resources in 2015 would, according to our estimations, equal $\mathrm{Rb} 5.6$ trillion, adding $\mathrm{Rb} 0.3$ trillion to the actual volume.

The decline may be of local nature and for a short period of time, like that in 2009, and recovery to economically normal level of enterprises' propensity to finance investments from own resources can generate about $\mathrm{Rb} 6.6$ trillion of fixed investment from enterprises' own resources in 2016.

However, this also may be the beginning of a longer period of decline in enterprises' propensity to finance fixed investment from own resources due to deterioration of the business climate (both general economic situation and adverse trends in the investment climate). With enterprises' propensity to finance investment projects from own resources staying as low as $44.5 \%$ in 2016 and based on the estimated volume of own resources for investment generated in 2015, one can expect fixed investment from enterprises' own resources to run at about $\mathrm{Rb} 6.2$ trillion.

Economic enterprises, based on the disposable profit generated in 2015, have great opportunities to increase self-financing for fixed investment in 2016. Investment from enterprises' own resources may grow by Rb 1.3 trillion under the best-case scenario, and by nearly $\mathrm{Rb} 1$ trillion under the business-as-usual scenario, which may contribute about $6.5-9 \%$ of nominal growth in fixed investment.

Within the period of investment pause, 2016 may turn out to be the year of most active nominal expansion of fixed investment. 